\title{
MENINGKATKAN KEMAMPUAN PEMAHAMAN MATEMATIK SISWA SMP MELALUI PENDEKATAN PEMBELAJARAN BERBASIS MASALAH
}

\author{
Usman Aripin \\ usmanaripin@gmail.com
}

Program Studi Pendidikan Matematika, STKIP Siliwangi

\begin{abstract}
ABSTRAK
Penelitian ini dilatar belakangi oleh masih rendahnya kemampuan pemahaman matematik siswa Sekolah Menengah Pertama diperlukan pendekatan pembelajaran untuk mengatasi masalah tersebut. Alternatif pendekatan yang diterapkan yaitu dengan pendekatan pembelajaran berbasis masalah. Penelitian ini bertujuan untuk mengetahui apakah peningkatan kemampuan pemahaman matematik siswa yang pembelajarannya menggunakan pendekatan pembelajaran berbasis masalah lebih baik daripada pendekatan konvensional. Metode penelitian yang digunakan adalah metode eksperimen. Pada awal dan akhir pembelajaran kedua kelas diberi tes. Populasi dalam penelitian ini adalah siswa SMP kabupaten bandung barat, sedangkan sampelnya terdiri dari dua kelas yang dipilih secara acak kelas, diperoleh kelas VIII-3 sebagai kelas eksperimen dan kelas VIII-4 sebagai kelas kontrol. Pengumpulan data dalam penelitian ini berupa tes sebanyak 5 soal uraian, kemudian data skor kemampuan pemahaman matematik tersebut dianalisis dengan statistik deskriptif dan inferensial dengan menggunakan uji perbedaan dua ratarata. Berdasarkan hasil penelitian, baik dari hasil analisis data maupun pengujian hipotesis, maka penulis menyimpulkan bahwa peningkatan kemampuan pemahaman matematik siswa yang pembelajarannya menggunakan pendekatan pembelajaran berbasis masalah lebih baik daripada yang menggunakan pendekatan konvensional.
\end{abstract}

Kata Kunci: Kemampuan Pemahaman, Pendekatan Pembelajaran Berbasis Masalah.

\begin{abstract}
This research is motivated by the poor ability of understanding mathematical junior secondary students learning approach is needed to resolve the issue. Alternative approaches were applied, namely the problem-based learning approach. This study aims to determine whether the increased understanding of the mathematical ability of students learning using problem-based learning approach is better than the conventional approach. The method used was experimental method. At the beginning and end of the study both classes were given the test. The population in this study is the county junior high school students bandung west, while the sample is composed of two classes randomly selected classes, derived classes VIII-3 as the experimental class and VIII-4 as the control class. Collecting data in this study a test as much as 5 about description, then the ability of understanding mathematical score data were analyzed using descriptive and inferential statistics using two different test average. Based on the research results, both from the results of the data analysis and hypothesis testing, the authors concluded that increased understanding of the mathematical ability of students learning using problem-based learning approach was better than using the conventional approach.
\end{abstract}

Keywords: Ability Understanding, Problem Based Learning Approach.

\section{A. PENDAHULUAN}

Matematika merupakan aktivitas manusia. Semua orang melakukan aktivitas matematika mulai dari ibu rumah tangga, pedagang, pegawai, pelajar, matematikawan dsb, sesuai dengan kebutuhannya masing-masing. Misalnya seorang ibu rumah tangga akan memasak untuk keluarganya dengan biaya sekian rupiah berpikir bagaimana caranya dengan biaya tersebut mendapatkan hasil yang maksimal. Beliau akan melakukan perhitungan, penalaran sampai dengan logika bepikirnya sehingga dapat memutuskan apa yang akan dilaksanakan. 
Dewasa ini salah satu problematika siswa dalam belajar adalah matapelajaran matematika. Sudah menjadi rahasia umum bahwa bagi kebanyakan siswa matematika dianggap matapelajaran yang sukar. Padahal matematika itu salah satu pelajaran yang penting untuk dikuasai, karena hampir disetiap jenjang pendidikan terdapat matematika. Selain itu dalam penilaian kompetensi seseorang salahsatu istrumennya soal matematika, seperti tes masuk kerja, perguruan tinggi dsb. Oleh sebab itu setiap orang penting untuk memahami matematika.

Kemampuan pemahaman matematika sangatlah penting dikuasai siswa karena belajar matematika bukan hanya sekedar hafal rumus dan bisa menghitung saja tetapi harus bisa memahami konsepnya. Hal ini sesuai dengan pendapat Purwanto (Harja: 2012), bahwa pemahaman adalah tingkat kemampuan yang mengharapkan siswa mampu memahami arti atau konsep, situasi serta fakta yang diketahuinya.

Pemahaman matematis juga merupakan salah satu kompetensi yang harus dicapai. Hal ini sesuai dengan Depdiknas (2003:2) bahwa, pemahaman konsep merupakan salah satu kecakapan atau kemahiran matematika yang diharapkan dapat tercapai dalam belajar matematika. Namun kenyataan dilapangan menurut Suwarti (2013:51) hasil angket pemahaman matematik dapat disimpulkan bahwa siswa masih mengalami kesulitan pada tingkat kemampuan pemahaman matematik hal ini berarti kemampuan pemahaman matematik siswa masih rendah.

Peran guru merupakan salahsatu peran penting dalam keberhasilan proses pembelajaran. Slameto (2003:163), "Salah satu kemampuan yang harus dimiliki seorang guru adalah mampu menggunakan banyak pendekatan saat mengajar...”. Proses pembelajaran dikelas akan lebih menarik, tidak monoton dan memotivasi siswa untuk belajar lebih aktif, sehingga dalam upaya meningkatkan kemampuan pemahaman matematika hendaknya dapat memilih dan menerapakan suatu pembelajaran yang efektif.

Mengatasi permasalahan diatas maka diperlukan pendekatan pembelajaran yang mudah dipahami siswa dan mendorong siswa untuk aktif dalam mencapai kompetensi yang diharapkan. Banyak metode pengajaran matematika yang relevan, salah satunya adalah menerapkan pendekatan pembelajaran berbasis masalah (Problem Based Learning) dalam pembelajaran matematika.
Pembelajaran berbasis masalah merupakan suatu pembelajaran yang menggunakan masalah sebagai peran utama dalam keberhasilan proses pembelajaran. Menurut Soedjadi (Tanti, 2012), 'Pendekatan pembelajaran berbasis masalah memulai pembelajaran dengan masalah yang kompleks misalnya tentang hal-hal dalam kehidupan sehari-hari, kemudian dikupas menuju kepada konsep-konsep sederhana yang terkait'. Hal ini dilakukan supaya siswa mengetahui manfaat matematika dalam kehidupan dan termotivasi untuk memecahakan permasalahannya.

Menurut Sudrajat(2011) pendekatan pembelajaran berbasis masalah memiliki beberapa keunggulan, diantaranya:

1. Siswa lebih memahami konsep yang diajarkan sebab mereka sendiri yang menemukan konsep tersebut;

2. Melibatkan secara aktif memecahkan masalah dan menuntut keterampilan berpikir siswa yang lebih tinggi;

3. Pengetahuan tertanam berdasarkan skema yang dimiliki siswa sehingga pembelajaran lebih bermakna;

4. Siswa dapat merasakan manfaat pembelajaran sebab masalah-masalah yang diselesaikan langsung dikaitkan dengan kehidupan nyata, hal ini dapat meningkatkan motivasi dan ketertarikan siswa terhadap bahan yang dipelajari;

5. Menjadikan siswa lebih mandiri dan dewasa, mampu memberi aspirasi dan menerima pendapat orang lain, menanamkan sikap sosial yang positif diantara siswa.

6. Pengkondisian siswa dalam belajar kelompok yang saling berinteraksi terhadap pembelajar dan temannya sehingga pencapaian ketuntasan belajar siswa dapat diharapkan.

Dilihat dari keunggulannya pendekatan ini diharapkan dapat meningkatkan kemampuan pemahaman matematik siswa karena siswa menemukan konsep sendiri yang berimplikasi lebih memahami, mandiri dalam belajar serta mempunyai keterampilan memecahkan masalahmasalah matematika.

Berdasarkan permasalahan di atas, maka dalam hal ini peneliti merumuskan masalah yaitu apakah peningkatan kemampuan pemahaman matematik siswa yang pembelajarannya menggunakan pendekatan pembelajaran berbasis masalah lebih baik dari pada yang pembelajarannya menggunakan pendekatan konvensional? 
Sejalan dengan permasalahan diatas maka secara garis besar penelitian ini bertujuan untuk mengetahui apakah peningkatan kemampuan pemahaman matematik siswa yang pembelajarannya menggunakan pendekatan pembelajaran berbasis masalah lebih baik dari pada yang pembelajaranya menggunakan pendekatan konvensional.

\section{B. KAJIAN TEORI DAN METODE}

\section{Kajian Teori}

\section{a. Kemampuan Pemahaman Matematik}

Pemahaman merupakan suatu kemampuan mengerti suatu permasalahan. Dalam matematika pemahaman bukan hanya sekedar hafal rumus atau bisa menghitung tetapi mengetahui kebenaran rumus atau konsep dalam matematika. Bloom (Ruseffendi, 2006:221) menyatakan, "Ada 3 macam pemahaman: pengubahan (translation), pemberian arti (interpretation), dan pembuatan ekstrapolasi (extrapolation)". Implementasi menurut Polya (Sumarmo, 1987) merinci kemampuan pemahaman pada empat tingkat yaitu:

1) Pemahaman mekanikal merupakan kemampuan mengingat dan menerapkan rumus secara rutin dan sederhana.

2) Pemahaman induktif merupakan kemampuan menerpakan rumus atau konsep dalam kasus sederhana atau dalam kasus serupa.

3) Pemahaman rasioanal merupakan membuktikan kebenaran suatu rumus dan teorema.

4) Pemaham intuitif merupakan memperkirakan kebenaran dengan pasti (tanpa ragu-ragu) sebelum menganalisis lebih lanjut.

Pollatsek dan Skemp (Sumarmo, 2010a) pemahaman dibedakan dua tingkat yaitu:

1) Pemahaman instrumental merupakan kemampuan hafal konsep ataupun rumus dan menerapkannya dalam perhitungan sederhana tanpa ada kaitan dengan konsep lain. Kemampuan ini tergolong pada kemampuan berfikir matematis tingkat rendah.

2) Pemahaman relasional merupakan kemampuan mengkaitkan satu konsep atau prinsip dengan konsep atau prinsip lainnya. Kemampuan ini tergolong kemampuan tingkat tinggi

Indikator dari pemahaman relasional menurut Skemp, mengacu pada indikator pemahaman menurut Kilpatrick dan Findell (Susanti, 2012) yaitu:
1) Kemampuan menyatakan ulang konsep dan menerapkan konsep secara alogaritma.

2) Kemampuan mengklasifikasi objek-objek berdasarkan dipenuhi atau tidaknya persyaratan yang telah membentuk konsep tersebut.

3) Kemampuan memberikan contoh dari konsep yang dipelajari dan menyajikan konsep dalam bentuk representasi matematika.

4) Kemampuan mengaitkan berbagai konsep matematika.

Berdasarkan literatur diatas maka kemampuan pemahaman matematik dalam penelitian ini adalah menyatakan ulang, mengklasifikasai objek-objek, menyajikan, menerapkan dan mengaitkan berbagi konsep matematika.

\section{b. Pendekatan Pembelajaran Berbasis Masalah (problem based learning)}

Pembelajaran berbasis masalah yaitu suatu pembelajaran yang menyajikan masalah diawal pemebelajaran yang menuntut aktivitas mental siswa supaya memahami suatu konsep pembelajaran (Ratnaningsih, 2003). Sedangkan menurut suryatno (Tanti,2012) menyatakan bahwa, pembelajaran yang titik awal pembelajaran dimulai berdasarkan masalah dalam kehidupan nyata siswa dirangsang untuk mempelajari masalah berdasarkan pengetahuan dan pengalaman telah mereka miliki sebelumnya (prior knowledge) untuk membentuk pengetahuan dan pengalaman baru

Tujuan pemberian masalah diawal pembelajaran supaya siswa mengetahui manfaat matematika dalam kehidupan nyata dan terrmotivasi untuk menyelesaikannya. Pentingya mengetahui tujuan pembelajaran karena siswa yang tidak tertarik pada matapelajaran matemaika salah satunya karena siswa tidak mengerti manfaat dan tujuan matematika itu sendiri.

Masalah merupakan titik awal pembelajaran supaya memahami konsep dan berlatih memecahkan masalah. Dalam pembelajaran berbasis masalah guru bertidak sebagai fasilitator pembelajaran artinya yang lebih banyak beperan adalah siswa. Guru membantu mengarahkan siswa untuk melakukan penemuan solusi permasalahan. Implikasinya siswa dituntut untuk belajar mandiri dalam menyelesaikan masalah yang ada, dengan bekerja sama mencari informasi dan menganalisis permasalahan untuk menemukan solusinya. 
Pierce dan Jones (Ratnaningsih, 2003) mengatakan hal-hal yang harus terjadi dalam proses pembelajaran berbasis masalah adalah sebagai berikut:

1) Keterlibatan meliputi mempersiapkan siswa untuk berperan sebagai pemecah masalah yang bisa bekerja sama dengan pihak lain, menghadapkan siswa pada situasi yang mendorong untuk mempu menemukan masalah dan meneliti permasalahan sambil mengajukan dugaan dan rencana penyelesaian.

2) Inkuiri dan investigasi yang mencakup kegiatan mengeksplorasi dan mendistribuskan informasi.

3) Performansi yaitu menyajikan temuan.

4) Tanya jawab yaitu menguji keakuratan dari solusi dan melakukan refleksi terhadap proses pemecahan masalah.

Depdiknas (2003), ciri utama pembelajaran berbasis masalah meliputi mengorientasikan siswa kepada masalah atau pertanyaan yang autentik. multidisiplin, menuntut kerjasama dalam penyelidikan, dan menghasilkan karya. Kemudian ciri utama pendekatan pembelajaran berbasis masalah menurut Trianto (Tanti, 2012) sebagai berikut :

1. Pengajuan pertanyaan atau masalah.

Guru memunculkan pertanyaan yang nyata di lingkungan siswa serta dapat diselidiki oleh siswa kepada masalah yang autentik ini dapat berupa cerita, penyajian fenomena tertentu, atau mendemontrasikan suatu kejadian yang mengundang munculnya permasalahan atau pertanyaan.

2. Berfokus pada keterkaitan antar disiplin.

Meskipun pembelajaran berdasarkan masalah mungkin berpusat pada mata pelajaran tertentu (IPA, matematika, ilmu-ilmu sosial) masalah yang dipilih benar-benar nyata agar dalam pemecahannya, siswa dapat meninjau dari berbagi mata pelajaran yang lain.

3. Penyelidikan autentik.

Pembelajaran berdasarkan masalah mengharuskan siswa melakukan penyelidikan autentik untuk mencari penyelesaian nyata terhadap masalah yang disajikan. Metode penyelidikan ini bergantung pada masalah yang sedang dipelajari.

4. Menghasilkan produk atau karya.

Pembelajaran berdasarkan masalah menuntut siswa untuk menghasilkan produk tertentu dalam bentuk karya dan peragaan yang menjelaskan atau mewakili bentuk penyelesaian masalah yang mereka temukan. Produk itu dapat juga berupa laporan, model fisik, video maupun program komputer

5. Kolaborasi.

Pembelajaran berdasarkan masalah dicirikan oleh siswa yang bekerja sama satu dengan yang lainnya, paling sering secara berpasangan atau dalam kelompok kecil. Bekerjasama untuk terlibat dan saling bertukar pendapat dalam melakukan penyelidikan sehingga dapat menyelesaikan permasalahan yang disajikan.

Setiap pembelajaran apapun terdapat kelebihan ataupun kekurangan. Kelebihan pembelajaran berbasis masalah sebagai suatu pendekatan pembelajaran menurut Widyastuti (2010) adalah:

(a) Realistik dengan kehidupan siswa.

(b) Konsep sesuai dengan kebutuhan siswa.

(c) Memupuk sifat inkuiri siswa.

(d) Retensi konsep menjadi kuat.

(e) Memupuk kemampuan problem solving.

Selain itu, kekurangannya adalah

(1) Persiapan pembelajaran (alat, problem, konsep) yang kompleks.

(2) Sulitnya mencari problem yang relevan.

(3) Sering terjadi miss-konsepsi.

(4) Memerlukan waktu yang cukup panjang.

Sintaks suatu pembelajaran menurut Widyastuti (2010) berisi langkah-langkah yang harus dilakukan oleh guru dan siswa. Terdapat 5 langkah-langkah dalam pembelajaran berbasis masalah yaitu sebagai berikut :

\section{Tabel 1. Langkah- Langkah Pembelajaran} Berbasis Masalah

\begin{tabular}{|c|c|}
\hline Tahap & Tingkah Laku guru \\
\hline $\begin{array}{l}\text { Tahap-1 } \\
\text { Orientasi siswa pada } \\
\text { masalah }\end{array}$ & $\begin{array}{l}\text { Guru menjelaskan tujuan pembelajaran, } \\
\text { menjelaskan logistik yang dibutuhkan, } \\
\text { mengajukan fenomena atau demonstrasi } \\
\text { atau cerita untuk memunculkan } \\
\text { masalah, memotivasi siswa untuk } \\
\text { terlibat dalam pemecahan masalah yang } \\
\text { dipilih. }\end{array}$ \\
\hline $\begin{array}{l}\text { Tahap-2 } \\
\text { Mengorganisasi } \\
\text { siswa untuk belajar }\end{array}$ & $\begin{array}{l}\text { Guru membantu siswa untuk } \\
\text { mendefinisikan dan mengorganisasi } \\
\text { tugas belajar yang berhubungan dengan } \\
\text { masalah tersebut }\end{array}$ \\
\hline $\begin{array}{l}\text { Tahap-3 } \\
\text { Membimbing } \\
\text { penyelidikan } \\
\text { individual maupun } \\
\text { kelompok }\end{array}$ & $\begin{array}{l}\text { Guru mendorong siswa untuk } \\
\text { mengumpulkan informasi yang sesuai, } \\
\text { melaksanakan eksperimen untuk } \\
\text { mendapatkan penjelasan dan } \\
\text { pemecahan masalah. }\end{array}$ \\
\hline $\begin{array}{l}\text { Tahap-4 } \\
\text { Mengembangkan dan } \\
\text { menyajikan hasil } \\
\text { karya }\end{array}$ & $\begin{array}{l}\text { Guru membantu siswa dalam } \\
\text { merencanakan dan menyiapkan karya } \\
\text { yang sesuai seperti laporan, video, dan } \\
\text { pendekatan serta membantu mereka } \\
\text { untuk berbagi tugas dengan temannya. }\end{array}$ \\
\hline
\end{tabular}


Tahap-5

Menganalisis dan mengevaluasi proses

pemecahan masalah
Guru membantu siswa untuk melakukan refleksi atau evaluasi terhadap penyelidikan mereka dan proses-proses yang mereka gunakan.

Perbedaan pembelajaran berbasis masalah dengan pembelajaran konvensional menurut Sumarmo $(2014,150)$ adalah terletak pada penyajian masalah. Dalam pembelajaran konvensional penyajian masalah diletakan diakhir pembelajaran sebagai latihan dan penerapan konsep yang dipelajari sedangkan pembelajaran berbasis masalah disajikan diawal pembelajaran, berfungsi untuk mendorong pencapaian konsep melalui investigasi, inkuiri, pemecahan masalahdan mendorong kemandirian belajar.

Berdasarkan studi literatur dan permasalahan yang dirumuskan pada bagian sebelumnya, hipotesis dalam penelitian ini adalah peningkatan kemampuan pemahaman matematik siswa yang pembelajarannya menggunakan pendekatan berbasis masalah lebih baik daripada yang pembelajarannya menggunakan pendekatan konvensional.

\section{Metode}

Metode penelitian yang digunakan adalah eksperimen. Penelitiaan ini terdapat perlakuan khusus pada kelas eksperimen yaitu pembelajaran dengan menggunakan pendekatan Pembelajaran Bebasis Masalah (Problem Based Learning) sedangkan pada kelas kontrol menggunakan pembelajaran konvensional.

Menurut Ruseffendi (2010:50) "Penelitian eksperimen murni adalah pengelompokan subjek secara acak. Disain penelitian eksperimen murni yang diambil kontol pretes-postes (pretest-posttestcontrol group disign)". Sebelum dan sesudah pembelajaran yang dilaksanakan kelas eksperimen dan kontrol diberi tes awal (pretest) dan tes akhir (posttest). Rancangan yang digunakan dalam penelitian ini di sajikan sebagai berikut (Ruseffendi, 2010:50):

$$
\begin{array}{llll}
\mathrm{A} & \mathrm{O} & \mathrm{X} & \mathrm{O} \\
\mathrm{A} & \mathrm{O} & \mathrm{O}
\end{array}
$$

Keterangan:

A = Pengambilan sampel secara acak kelas

$\mathrm{O}=$ Tes awal $=$ Tes akhir

$\mathrm{X}=$ Perlakuan pembelajaran berorientasi pendekatan pembelajaran berbasis masalah

Populasi seluruh siswa kelas VIII SMP Kabupaten Bandung Barat. Sedangkan yang menjadi sampelnya dipilih dua kelas secara acak, dimana kelas yang satu menjadi kelas eksperimen dan kelas yang lain adalah kelas kontrol. Alasan memilih sampel ini karena memiliki karakteristik yang dapat mewakili populasi. Karakteristik yang dimaksud adalah kemampuan pemahaman matematika.

Tes yang digunakan untuk mengukur kemampuan pemahaman matematika terdiri dari lima butir soal berbentuk uraian. Uji coba instrumen dilakukan sebelum penelitian dilaksanakan. Setelah itu agar memilki validitas empiris soal-soal tersebut diujicobakan dan kemudian dihitung validitas, reliabilitas, daya pembeda dan indeks kesukarannya. Untuk mengetahui seberapa besar peningkatan kemampuan pemahaman matematik siswa sebelum dan setelah kegiatan pembelajaran, dilakukan analisis skor gain ternormalisasi dengan perhitungan gain ternormalisasi dari Hake (Hidayat, 2011 : 35) sebagai berikut :

$$
\mathrm{g}=\frac{\text { skor tes akhir-skor tes awal }}{\text { skor maksimum ideal-skor tes awal }}
$$

Tingkat perolehan skor gain ternormalisasi dikelompokkan kedalam tiga kategori, yaitu :
$0,70<(\mathrm{g}) \quad$ : Tinggi
$0,30 \leq(\mathrm{g}) \leq 0,70 \quad:$ Sedang
$(\mathrm{g})<0,30 \quad:$ Rendah

Teknik pengolahan data dilakukan dengan menggunakan bantuan software MINITAB 16 .

\section{HASIL PENELITIAN DAN PEMBAHASAN}

\section{Hasil}

Rekapitulasi hasil penelitian kemampuan pemahaman matematik siswa antara yang pembelajarannya pendekatan berbasis masalah dengan pendekatan konvensional disajikan dalam tabel berikut:

\begin{tabular}{|c|c|c|c|c|c|c|}
\hline & \multicolumn{3}{|c|}{ Eksperimen } & \multicolumn{3}{|c|}{ Kontrol } \\
\hline & pretes & postes & gain & pretes & postes & gain \\
\hline$n$ & & 28 & & & 25 & \\
\hline $\bar{x}$ & 1,36 & 9,93 & 0,52 & 1,16 & 7,28 & 0,36 \\
\hline$S$ & 1,54 & 4,03 & 0,22 & 1,03 & 2,61 & 0,16 \\
\hline
\end{tabular}

Tabel 1. Rekapitulasi Hasil Penelitian Kemampuan Pemahaman Matematik

Keterangan:

Skor Maksimum Ideal (SMI) Kemampuan Pemahaman Matematik $=20$ 
Bedasarkan tabel 1 rerata gain kelas eksperimen dan gain kelas kontrol yaitu 0,52 dan 0,36 dengan simpangan baku masing-masing 0,22 dan 0,16 artinya secara deskriptif peningkatan kemampuan pemahaman kelas eksperimen lebih baik daripada kelas kontrol. Selanjutnya untuk mendukung deskripsi kemampuan pemahaman matematik yang telah dijelaskan, maka dilakukan analisis data kemampuan pemahaman matematik siswa melalui uji statistik dengan menggunakan bantuan software MINITAB 16 dan didapat hasil sebagai berikut:

Tabel 2. Rekapitulasi Pengujian Perbedaan Rerata Data Gain Kemampuan Pemahaman Matematik

\begin{tabular}{ccccccc}
\hline Kelas & $\mathrm{N}$ & $\overline{\mathrm{x}}$ & $\mathrm{S}$ & $\mathrm{t}_{\text {hit }}$ & $\mathrm{P}$ & Interpretasi \\
\hline Eksperimen & 28 & 0,52 & 0,04 & 2,97 & 0,004 & \multirow{2}{*}{$\mathrm{H}_{0}$ di tolak } \\
Kontrol & 25 & 0,36 & 0,03 & & & \\
\hline
\end{tabular}

Terlihat pada Tabel 2 di dapat $\mathrm{P}$ sebesar 0,004 karena $\mathrm{P}<0,05$ dengan kata lain $\mathrm{H}_{0}$ ditolak artinya terdapat perbedaan peningkatan kemampuan pemahaman matematik siswa antara yang pembelajarannya menggunakan pendekatan pembelajaran berbasis masalah dengan pendekatan konvensional pada taraf signifikansi $5 \%$.

Nilai rerata gain kelas eksperimen 0,52 berbeda secara signifikan dengan rerata gain kelas kontrol 0,36. Karena rerata kelas eksperimen lebih besar dengan kelas kontrol maka dapat disimpulkan bahwa peningkatan kemampuan pemahaman matematik siswa yang pembelajarannya menggunakan pendekatan pembelajaran berbasis masalah lebih baik dari pada yang pembelajarannya menggunakan pendekatan konvensional.

Selanjutnya akan di uji kemampuan pemahaman matematik yang lebih baik antara kelas eksperimen dan kontrol terlebih dahulu menguji pretes untuk memastikan bahwa kedua kelas tersebut berangkat dari kemampuan yang sama. Berikut hasil pengujian:

Tabel 3. Rekapitulasi Pengujian Perbedaan Rerata Data Pretes Kemampuan Pemahaman Matematik

\begin{tabular}{ccccccc}
\hline Kelas & $\mathrm{N}$ & $\overline{\mathrm{x}}$ & $\mathrm{S}$ & $\mathrm{t}_{\text {hit }}$ & $\mathrm{P}$ & Interpretasi \\
\hline Eksperimen & 28 & 1,36 & 1,54 & \multirow{2}{*}{0,55} & 0,58 & $\mathrm{H}_{0}$ Diterima \\
Kontrol & 25 & 1,16 & 1,03 & & & \\
\hline
\end{tabular}

Terlihat pada Tabel 3 di dapat $\mathrm{P}$ sebesar 0,58 hal ini berarti $\mathrm{P}>0,05$ dengan kata lain $\mathrm{H}_{0}$ diterima . Hal ini berarti tidak terdapat perbedaan kemampuan awal pemahaman matematik siswa antara kelas eksperimen dengan kelas kontrol dengan taraf signifikansi 5\%. Karena kedua sampel berangkat dari kemampuan yang sama, dapat di bandingkan kemapuan pemahaman matematika antara kelas eksperimen dan kelas kontrol. Adapun pengujiannya sebagai berikut:

Tabel 4. Rekapitulasi Pengujian Perbedaan Rerata Data Postes Kemampuan Pemhaman Matematik

\begin{tabular}{ccccccc}
\hline Kelas & $\mathrm{N}$ & $\overline{\mathrm{x}}$ & $\mathrm{S}$ & $\mathrm{t}_{\text {hit }}$ & $\mathrm{P}$ & Interpretasi \\
\hline Eksperimen & 28 & 9,93 & 4,03 & \multirow{2}{*}{2,87} & \multirow{2}{*}{0,006} & \multirow{2}{*}{$\mathrm{H}_{0}$ di tolak } \\
Kontrol & 25 & 7,28 & 2,61 & & & \\
\hline
\end{tabular}

Terlihat pada Tabel 4 di dapat $\mathrm{P}$ sebesar 0,006 karena $\mathrm{P}<0,05$ dengan kata lain $\mathrm{H}_{0}$ ditolak artinya terdapat perbedaan kemampuan pemahaman matematik siswa antara yang pembelajarannya menggunakan pendekatan pembelajaran berbasis masalah dengan pendekatan konvensional pada taraf signifikansi 5\%.

Nilai rerata postes kelas eksperimen 9,93 berbeda secara signifikan dengan rerata postes kelas kontrol 7,28. Karena rerata kelas eksperimen lebih besar dengan kelas kontrol maka dapat disimpulkan bahwa kemampuan pemahaman matematik siswa yang pembelajarannya menggunakan pendekatan pembelajaran berbasis masalah lebih baik dari pada yang pembelajarannya menggunakan pendekatan konvensional.

\section{Pembahasan}

Pembelajaran berbasis masalah dimulai dengan masalah untuk membuat interaksi terhadap materi pembelajaran dan memberikan pengetahuan tentang manfaatnya dalam kehidupan. Siswa lebih antusias dalam belajar karena siswa mengetahui tujuan dan manfaat dari suatu materi. Dalam proses pembelajaran siswa lebih aktif dan lebih memahami karena peran guru hanya sebagai fasilitator dan berpusat pada siswa dibandingkan dengan pendekatan konvensional yang berpusat pada guru.

Berdasarkan analisis kemampuan awal siswa skor pretes kedua kelompok menunjukan tidak terdapat perbedaan yang signifikan. Kemudian kedua kelompok tersebut diberi perlakuan yang berdeda yaitu, kelompok eksperimen mendapatkan perlakuan berupa pendekatan pembelajaran berbasis masalah sedangkan kelompok kontrol mendapatkan pembelajarn konvensional. 
Selanjutnya dari hasil perhitungan gain ternormalisasi, jika dilihat secara keseluruhan ratarata peningkatan pemahaman matematik siswa kelas eksperimen adalah 0,52 (berada pada klasifikasi sedang) dan rata-rata peningkatan kemampuan pemahaman siswa kelas kontrol adalah 0,36 (bearada pada klasifikasi sedang. Dilihat dari reratanya, peningkatan kemampuan pemahaman matematik siswa kelas eksperimen besar daripada kelas kontrol. Nilai $\mathrm{P}=0,002$, maka $\mathrm{P}<0,05$ dapat disimpulkan bahwa kemampuan pemahaman matematik siswa yang pembelajarannya menggunakan pendekatan berbasis masalah lebih baik daripada yang pembelajrannya menggunakan pendekatan konvensional.

Terkadang peningkatannya lebih baik belum tentu kemampuan akhirnya juga lebih baik maka dari itu peneliti menganalisis data postes untuk melihat kemampuan pemahaman matematik siswa kelas eksperimen dan kelas kontrol. Kemudian rerata postes kelas eksperimen sebesar 9,93 dan rerata postes kelas kontrol sebesar 7,28 dengan skor maksimum idealnya 18 . Secara deskriptif rerata kelas eksperimen lebih besar daripada rerata kelas kontrol. Selanjutnya hasil uji t' menunjukan $\mathrm{P}=$ 0,003 maka $\mathrm{P}<0,05$ artinya $\mathrm{H}_{0}$ ditolak, dapat disimpulkan bahwa kemampuan pemahaman matematika siswa yang pembeljarannya menggunakan pendekatan berbasis masalah lebih baik daripada pendekatan konvensional.

Oleh karena itu pendekatan pembelajaran berbasis masalah direkomendasikan untuk digunakan pada topik-topik tertentu. Pembelajaran berbasis masalah mempunyai kelebihan diantaranya dapat membuat siswa lebih memaknai matematika karena masalah yang disajikan dalam pembelajaran masalah kehidupan sehari-hari. Siswa dituntut untuk melakukan pemecahan masalah yang ada dengan mencari informasi, kemudian dianalisis dan diselesaikan menggunakan konsep matematika yang relevan dengan masalah tersebut mengakibatkan siswa lebih memahami matematika.

\section{KESIMPULAN}

Berdasarkan analisis data dan pembahasan yang telah dikemukakan pada bab sebelumnya maka dapat ditarik kesimpulan bahwa peningkatan kemampuan pemahaman matematik siswa yang pembelajarannya menggunakan pendekatan pembelajaran berbasis masalah lebih baik dari pada yang pembelajarannya menggunakan pendekatan konvensional.

\section{E. DAFTAR PUSTAKA}

Depdiknas (2003). Pedoman Khusus Pengembangan Sistem Penilaian Berbasis Kompetensi SMP. Jakarta: Depdiknas.

Harja (2012). Pemhaman Konsep Matematis.[Online]. Tersedia : http://mediaharja.blogspot.com/2012/05/pe mahaman-konsep-matematis.html[20April 2014]

Hidayat, W. (2011). Meningkatkan Kemampuan Berfikir Kritis dan Kreatif Matematik Siswa melalui Pembelajaran Kooperatif ThinkThalk-Write. Tesis FPIMPA UPI. Bandung: tidak diterbitkan.

Ratnaningsih, N. (2003). "Pengembangan Kemampuan Berfikir Matematik Siswa SMU melalui Pembelajaran Berbasis Masalah". Tesis Program Pasca Sarjana UPI. Bandung: Tidak diterbitkan

Ruseffendi, E. T. (2006). Pengantar kepada Membantu Guru Mengembangkan Kompetensinya dalam Pengajaran Matematika untuk Meningkatkan CBSA. Bandung: Tarsito

Ruseffendi, E. T. (2010). Dasar-Dasar Penelitian Pendidikan \& Bidang Non Eksakta Lainnya. Bandung: Tarsito

Slameto (2003). Belajar dan Factor-Faktor yang Mempengaruhinya. Jakarta: Rineka cipta

Sudrajat, A. (2011). Pembelajaran Berdasarkan Masalah-Problem Based Learning.[ Online]. Tersedia:

https://akhmadsudrajat.wordpress.com/2011/ 09/28/pembelajaran-berdasarkan-masalah/

Sumarmo, U. (1987). Kemampuan Pemahaman dan Penalaran Matematika Siswa SMA Dikaitkan dengan Kemampuan Penalaran Logika Siswa dan Beberapa Unsur Proses Belajar Mengajar. Disertasi UPI. Bandung: Tidak Diterbitkan

Sumarmo, U. (2014). Berpikir dan Disposisi Matematika serta Pembelajarannya. Bandung : Jurusan Pendidikan Matematika FPMIPA-UPI. 
Susanti, E. (2012). Perbandingan Peningkatan Kemampuan Pemahaman Matematis Siswa yang Pembelajarannya Menggunakan Model Cooperatif Learning Tie Giving Question and Getting Answer dengan yang menggunakan Model Langsung. Skripsi Jurusan Matematika STKIP Siliwangi Bandung: tidak diterbitkan .

Suwarti (2013). Kesulitan Tingkat Pemahaman Matematika SMP. [Studi Pemula]. Cimahi: Tidak diterbitkan.

Tanti (2012). Pendekatan Pembelajaran Berbasis Masalah. [Online]. Tersedia: http:// catatantanti.blogspot.com/2012/09/pendekat an-pembelajaran-berbasis-masalah. html [22 Januari 2012]

Widyastuti (2010). Pendekatan Pembelajaran Berbasis Masalah (Problem Based Learning) dan Pendekatan Pembelajaran Berbasis Konteks (Contextual Teaching and Learning). [Online]. Tersedia: http://blog. unsri.ac.id/widyastuti/pendidikan/pendekata n-pembelajaran-berbasis-masalah-problembased-learning-dan-pendekatan-pembelajar an-berbasis-konteks-contextual-teachingand-learning/mrdetail/14376/. [22 Januari 2012]. 